\title{
Age and Sex Related Alterations in Serum and Platelet Monoamine Oxidase
}

\author{
Ayșe Veral, Gülinnaz Alper, Gülriz Menteș and Biltan Ersöz
}

Ege University, Faculty of Medicine, Department of Biochemistry, Bornova, İzmir, Turkey

\begin{abstract}
Summary: The process of aging presents itself with various alterations in physiological events. Although the turnover of catecholamines increases with aging, there is a lack of response to catecholamines in target tissues. One of the key enzymes in catecholamine metabolism is monoamine oxidase. It has been suggested that tissue and serum monoamine oxidase activities show pathological alterations in various diseases while physiological fluctuations can also be detected in normals. The aim of this study is to determine the sex and age related changes of platelet and serum monoamine oxidase in healthy volunteers.
\end{abstract}

In this study, 75 healthy volunteers of different ages (21-80a) and sexes (40 females, 35 males) were included. Serum and platelet monoamine oxidase determinations were performed spectrophotofluorometrically by Tufvesson's (Scand J Clin Lab Invest 1970; 26:151-4) and Kraml's (Biochem Pharmacol 1965; 14:1684-6) modified methods, respectively.

While there was no significant difference in serum monoamine oxidase activities related to age and sex, platelet monoamine oxidase manifested a significant increase in females compared to males $(p<0.05)$ and the mean values in both sexes showed an increase with age $(\mathrm{p}<0.001)$.

The results of this study imply that platelet monoamine oxidase shows an age related increase which is more prominent in females.

\section{Introduction}

The process of aging, which has been an extensive area of investigation during recent years, manifests itself with various alterations in physiological events. It has been shown that with aging, the turnover of catecholamines increases, however, there is a lack of response to catecholamines in target tissues. The increases in the activities of the enzymes involved in catecholamine metabolism are held responsible for these changes $(1-6)$.

One of the key enzymes in catecholamine metabolism is monoamine oxidase (EC 1.4.3.4) which is an oxidoreductase that deaminates monoamines such as adrenaline, noradrenaline and dopamine $(7-8)$. There are two types of monoamine oxidase, one being a FAD containing enzyme (intracellular) located in the outer membrane of the mitochondria of many tissues such as platelets $(8-12)$ and the other, $\mathrm{a} \mathrm{Cu}^{2+}$ and pyridoxal phosphate containing enzyme found in serum (13). It has been suggested that while tissue and serum monoamine oxidase activities manifest abnormal alterations in various disease states $(13-26)$, physiological fluctuations may also be detected in normals $(8,27-30)$. The objective of this study has been to investigate the sex and age related fluctuations of platelet and serum monoamine oxidase in healthy volunteers.

\section{Materials and Methods}

Cases

In this study, conducted in the Hospital of Ege University School of Medicine with the permission of the Ethics Committee, 75 healthy volunteers of different ages $(21-80 \mathrm{a})$ and sexes (40 females, 35 males) were included. These volunteers were taking no medication or alcohol. They neither smoke nor suffer from any disorder.

\section{Reagents and solutions}

All reagents were analytical grade and purchased from Sigma Chem. Co. (St Louis) and Merck Darmstadt (Germany).

Assay

For serum monoamine oxidase determinations, $3 \mathrm{ml}$ venous blood, after coagulation, was centrifuged at $1500 \mathrm{~g}$ for 15 minutes to obtain the serum. For platelet monoamine oxidase determinations, $10 \mathrm{ml}$ venous blood samples were collected in polypropylene test tubes containing $0.5 \mathrm{ml}$ of $50 \mathrm{~g} / 1 \mathrm{Na}_{2}$ EDTA. For platelet isolation, Corash's platelet isolation method modified by Glover et al. (19) was applied. The sample was centrifuged at $320 \mathrm{~g}$ for $10 \mathrm{~min}$ and the platelet-rich plasma withdrawn and re-centrifuged at $2500 \mathrm{~g}$ for $15 \mathrm{~min}$. The platelet pellet was resuspended and washed in $1 \mathrm{ml}$ of $0.15 \mathrm{~mol} / 1 \mathrm{NaCl}$ and re-centrifuged at $2500 \mathrm{~g}$ for $15 \mathrm{~min}$. The pellet was resuspended in $1 \mathrm{ml}$ of $0.15 \mathrm{~mol} / 1 \mathrm{NaCl}$ and used for the measurement of monoamine oxidase. Platelet protein concentrations were assayed by the method of Lowry et al. (31).

Serum and platelet monoamine oxidase determinations were performed spectrophotofluorometrically (with the Aminco-Bowman spectrophotofluorometer) using Tufvesson's (32) and Kraml's (33) modified methods, respectively. The principle of both of these as- 
says is based on the spectrofluorometric measurement of the fluorescence of 4-hydroxyquinoline formed by the oxidative deamination of kynuramine via monoamine oxidase. The amount of 4-hydroxyquinoline formed is directly proportional to the monoamine oxidase activity of the sample.

\section{Statistical analysis}

For statistical analysis, variance analysis ( $\mathrm{F}$ test-one way ANOVA) and the Student $\mathrm{t}$ test were used.

\section{Results}

The mean platelet monoamine oxidase activities in different age groups and sexes are presented in table 1. As

Tab. 1 Platelet monoamine oxidase activities in different age groups and sexes.

\begin{tabular}{lrrlll}
\hline $\begin{array}{l}\text { Age } \\
\text { groups } \\
\text { (a) }\end{array}$ & \multicolumn{3}{l}{$\begin{array}{l}\text { Platelet monoamine oxidase activities } \\
\text { (nmol/h} \cdot \mathrm{mg} \text { protein) }\end{array}$} \\
\cline { 2 - 3 } & \multicolumn{2}{l}{ Females } & & \multicolumn{2}{l}{ Males } \\
\cline { 2 - 3 } \cline { 5 - 6 } & $\mathrm{n}$ & $\overline{\mathrm{x}} \pm \mathrm{SD}$ & & $\mathrm{n}$ & $\overline{\mathrm{x}} \pm \mathrm{SD}$ \\
\hline $21-30$ & 6 & $5.61 \pm 1.45$ & & 6 & $3.85 \pm 0.78$ \\
$31-40$ & 5 & $5.92 \pm 1.11$ & & 5 & \\
$41-50$ & 10 & $5.29 \pm 1.48$ & & 5 & $3.87 \pm 0.87$ \\
$51-60$ & 9 & $7.81 \pm 1.40$ & & 7 & $7.76 \pm 4.52$ \\
$61-70$ & 5 & $13.30 \pm 4.31$ & & 6 & $7.92 \pm 1.22$ \\
$71-80$ & 5 & $19.80 \pm 4.50$ & & 6 & $9.55 \pm 1.15$ \\
\hline
\end{tabular}

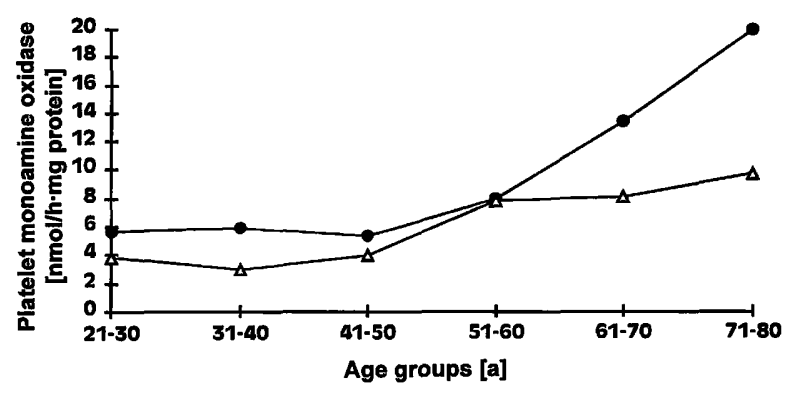

Fig. 1 Age-related changes in the mean values of platelet monoamine oxidase activities in different age groups in both sexes.

- - female

$-\Delta-$ male

may be observed in figure 1 , mean platelet monoamine oxidase activities increase with age (for females $\mathrm{p}<0.001$, for males $\mathrm{p}<0.005$ ).

The mean platelet monoamine oxidase activity of females $(8.80 \pm 5.43 \mathrm{nmol} / \mathrm{h} \cdot \mathrm{mg}$ protein) is significantly higher than that of males $(6.18 \pm 3.32 \mathrm{nmol} / \mathrm{h} \cdot \mathrm{mg}$ protein) $(p<0.05)$. The mean serum monoamine oxidase activity is $17.27 \pm 6.97 \mathrm{mU} / \mathrm{l}$ for females, while it is $18.21 \pm 7.03 \mathrm{mU} / 1$ for males. Although serum monoamine oxidase activity is higher in males than in females, the difference is not statistically significant (fig. 2).

The results of the age-related changes in serum monoamine oxidase activities in both sexes are presented in table 2. As may be observed in figure 2 , serum mono-
Tab. 2 Serum monoamine oxidase activities in different age groups and sexes.

\begin{tabular}{|c|c|c|c|c|}
\hline \multirow{3}{*}{$\begin{array}{l}\text { Age } \\
\text { groups } \\
\text { (a) }\end{array}$} & \multicolumn{4}{|c|}{ Serum monoamine oxidase $(\mathrm{mU} / \mathrm{l})$} \\
\hline & \multicolumn{2}{|c|}{ Females } & \multicolumn{2}{|c|}{ Males } \\
\hline & $\mathrm{n}$ & $\overline{\mathrm{x}} \pm \mathrm{SD}$ & $\mathbf{n}$ & $\overline{\mathrm{x}} \pm \mathrm{SD}$ \\
\hline $21-30$ & 6 & $16.28 \pm 3.94$ & 6 & $17.13 \pm 6.17$ \\
\hline $31-40$ & 5 & $17.56 \pm 3.12$ & 5 & $14.58 \pm 3.08$ \\
\hline $41-50$ & 10 & $14.53 \pm 4.24$ & 5 & $16.31 \pm 2.41$ \\
\hline $51-60$ & 9 & $19.60 \pm 11.1$ & 7 & $21.01 \pm 6.54$ \\
\hline $61-70$ & 5 & $15.56 \pm 4.16$ & 6 & $19.93 \pm 9.95$ \\
\hline $71-80$ & 5 & $21.14 \pm 6.49$ & 6 & $18.92 \pm 7.88$ \\
\hline
\end{tabular}

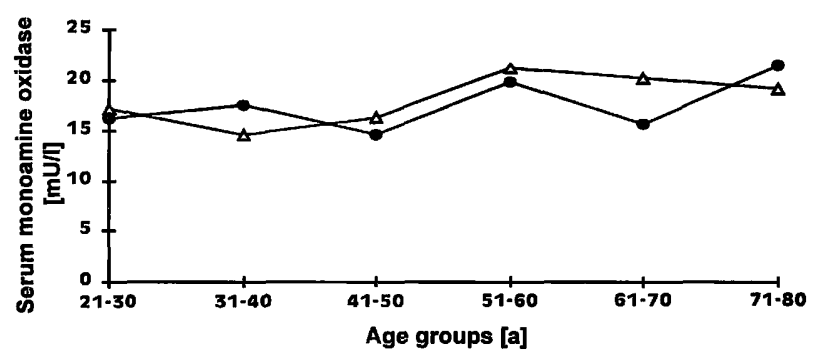

Fig. 2 Age-related changes in the mean values of serum monoamine oxidase activities in different age groups in both sexes.

- - female

$-\triangle-$ male

amine oxidase activities do not change related to age in either females or males.

\section{Discussion}

The results of the studies investigating the age and sex related changes in platelet and serum monoamine oxidase activities reveal contradictory data. Robinson et al. (4) in serum and platelets, Tryding et al. (26) in serum, Murphy et al. (34) and Bagdy \& Rihmer (35) in platelets and Benedetti et al. (5) in brain tissue noted an increase in monoamine oxidase activity with age. Meanwhile, Baron et al. (36) in platelets and Tryding et al. (26) in serum showed that monoamine oxidase activities were higher in females than in males. These investigators proposed that the higher activity of the enzyme in females is the result of the interaction between female sex hormones and monoamine oxidase $(26,36)$. However, in concordance with our results, most of the studies assaying serum monoamine oxidase activities reveal no significant differences related to age and sex $(8,27-30)$.

In our study, when the relationship between platelet monoamine oxidase activity and age was investigated, it was seen that in correlation with Robinson's et al. (4), Murphy's et al. (34) and Bagdy's \& Rihmer's (35) findings there was a significant correlation between aging and enzyme activity. Regardless of sex, mean platelet monoamine oxidase levels in different age groups manifested a significant increase with age $(p<0.001)$. When 
the females and males are evaluated separately, it is observed that platelet monoamine oxidase activities also increase with age in both sexes $(p<0.001$ in females and $p<0.005$ in males) (fig. 1).

It is observed that in all of the age groups mean platelet monoamine oxidase levels are higher in females than males. This increase in females is significantly higher in all groups $(p<0.05)$ except between the ages of 41-50 and 51-60 (tab. 1). Especially, the striking increase related to monoamine oxidase in females after the age of 60 is interesting. Our findings related to monoamine oxidase activity in females points to a possible link between female hormonal status and monoamine oxidase. However, this link is still obscure. Previously, Holzbauer \& Youdim (37) have observed a stimulating effect of progesterone on uterine, ovarian and adrenal monoamine oxidase activity. The information available being incomplete, it is not pos-

\section{References}

1. Gothries CG. Amine metabolism in normal ageing and in dementia disorders. In: Roberts PJ, editor. Biochemistry of dementia. New York: John Wiley \& Sons Ltd, chapter 10, 1980:213-68.

2. Insel PA. Adrenergic receptors, $G$ proteins and cell regulation: implications for ageing research. Exp Gerontol 1993; 28:341-8.

3. Robinson DS, Davis JM, Nies A, Colburn RW, Davis JN, Bourne HR, et al. Ageing, monoamines and monoamine oxidase levels. Lancet 1972; 5:290-1.

4. Robinson DS, Davis JM, Nies A, Ravaris CL, Sylwester D. Relation of sex and ageing to monoamine oxidase activity of human brain, plasma and platelets. Arch Gen Psychiatry 1971; 24:536-9.

5. Benedetti MS, Cini M, Fusi R. The effects of aging on monoamine oxidase activity and amino acid levels in rat brain. J Neural Transm 1990; 29 Suppl:259-68.

6. Venero JL, Machado A, Cano J. Determination of levels of biogenic amines and their metabolites and both forms of monoamine oxidase in prefrontal cortex of aged rats. Mech Ageing Dev 1990; 56:253-63.

7. Benedetti MS, Dostert P, Tipton KF. Developmental aspects of the monoamine-degrading enzyme monoamine oxidase. Dev Pharmacol Ther 1992; 18:191-200.

8. Nies A, Robinson DS, Lamborn KR, Lampert RP. Genetic control of platelet and plasma monoamine oxidase activity. Arch Gen Psychiatry 1973; 28:834-8.

9. Chuang HYK, Patek DR, Hellerman L. Mitochondrial monoamine oxidase. Inactivation by pargyline. Adduct formation. $\mathrm{J}$ Biol Chem 1974; 249 (8):2381-4.

10. Darracott-Cankovic S, Bitensky L, Chayen J. Histochemistry of monoamine oxidase activity. Cell Biochem Funct 1986; $4: 109-10$.

11. Glover V, Sandler M. Clinical chemistry of monoamine oxidase. Cell Biochem Funct 1986; 4:89-97.

12. Tipton KF. Enzymology of monoamine oxidase. Cell Biochem Funct $1986 ; 4: 79-87$.

13. Weyler W, Hsu YP, Breakefield XO. Biochemistry and genetics of monoamine oxidase. Pharmac Ther 1990; 47:391-417.

14. Alexopoulos GS, Lieberman KW, Young RC. Platelet monoamine oxidase activity in primary degenerative dementia. Am J Psychiatry 1984; 141(1):97-9.

15. Alexopoulos GS, Young RC, Lieberman KW, Shampian CA. Platelet monoamine oxidase activity in geriatric patients with depression and dementia. Am J Psychiatry 1987; 144(11): $1480-3$ sible to draw any general conclusion $(4,34,37)$. Further research in this area should be continued.

As to serum monoamine oxidase activity, no significant correlation between enzyme activity and sex is noted. Mean serum monoamine oxidase values are higher in males than in females but this increase is not statistically significant (tab. 2). Our results, related to serum monoamine oxidase activity, age and sex are in correlation with the previous studies $(8,27-30)$.

As a result, it is concluded that platelet monoamine oxidase activity increases with age, this change being more prominent in females.

Further detailed studies revealing the interaction between platelet monoamine oxidase activity and biogenic amine metabolism are necessary in order to elucidate the role of biogenic amines in the process of aging.

16. Devor EJ, Abel CW. Platelet monoamine oxidase activity in type I and II alcoholism. Ann NY Acad Sci 1994; 708:119-28.

17. Fischer $P$, Gotz ME, Ellinger $B$, Streifler $M$, Riederer $P$, Danielczyk W. Platelet monoamine oxidase $B$ activity and vi$\operatorname{tamin} B_{12}$ in dementia. Biol Psychiatry 1994; 35:772-4.

18. Friedman E, Shopsin B, Sathananthan G, Gershon S. Blood platelet monoamine oxidase activity in psychiatric patients. Am J Psychiatry 1974; 131 (12):1392-4.

19. Glover V, Peatfield R, Zammit-Pace R, Littlewood J, Gawel $\mathrm{M}$, Rose FC, et al. Platelet monoamine oxidase activity and headache. J Neurol Neurosurg Psychiatry 1981; 44:786-90.

20. Littlewood J, Glover V, Sandler M, Peatfield R, Petty R, Rose FC. Low platelet monoamine oxidase in headache: no correlation with phenolsulpho transferase, succinate dehydrogenase, platelet preparation method or smoking. J Neurol Neurosurg Psychiatry $1984 ; 47: 338-43$.

21. Littlewood J, Glover V, Sandler M, Petty R, Peatfield R, Rose FC. Migraine and cluster headache: links between platelet monoamine oxidase activity, smoking and personality. Headache $1984 ; 24: 30-4$.

22. Matsumoto T, Suzuki O, Furuta T, Asai M, Kurokawa Y, Nimura $\mathrm{Y}$, et al. A sensitive fluorometric assay for serum monoamine oxidase with kynuramine as substrate. Clin Biochem $1985 ; 18: 126-9$.

23. Murphy DL, Wyatt RJ. Reduced monoamine oxidase activity in blood platelets from schizophrenic patients. Nature 1972; 238:225-6.

24. Nakano H, Yamamoto $Y$, Ohnishi S, Ito K, Imura H. Serum monoamine oxidase assayed with a new synthetic benzylamine derivative as substrate. Its clinical significance with special reference to hepatic fibrosis. Clin Chim Acta 1978; 88:315-9.

25. Summers KM, Brown GK, Craig IW, Littlewood J, Peatfield $\mathrm{R}$, Glover V, et al. Platelet monoamine oxidase: specific activity and turnover number in headache. Clin Chim Acta 1982; 121:139-46.

26. Tryding N, Nilsson SE, Tufvesson G, Berg B, Carlström S, Elmfors B, et al. Physiological and pathological influences on serum monoamine oxidase level. Scand $\mathbf{J}$ Clin Lab Invest $1969 ; 23: 79-84$.

27. Bond PA, Cundall RL. Properties of monoamine oxidase (MAO) in human blood platelets, plasma, lymphocytes and granulocytes. Clin Chim Acta 1977; 80:317-26.

28. Mc Ewen JM, Cohen JD. An amine oxidase in normal human serum. J Lab Clin Med 1983; 62 (5):766-76. 
29. Konings CH, Kuiper MA, Wolters EC. More on monoamine oxidase activity in whole blood. Clin Chim Acta 1992; 205:145-7.

30. Oriente P, Postiglione L, Iovene MR. Evaluation of monoamine oxidase in the serum (SMAO) of clinically healthy volunteers. Boll Soc Ital Biol Sper 1979; 55:250-4.

31. Lowry OH, Rosebrough NJ, Farr AL, Randall RJ. Protein measurement with the folin-phenol reagent. J Biol Chem 1951; 193:265-75.

32. Tufvesson G. Fluorometric determination of amine oxidase activity in human blood serum with kynuramine as substrate. Scand J Clin Lab Invest 1970; 26:151-4.

33. Kraml M. A rapid microfluorometric determination of monoamine oxidase. Biochem Pharmacol 1965; 14:1684-6.

34. Murphy DL, Wright $\mathrm{C}$, Buchsbaum M, Nichols A, Costa JL, Wyatt RJ. Platelet and plasma amine oxidase activity in 680 normals: sex and age differences and stability over time. Biochem Med 1976; 16:254-65.

35. Bagdy G, Rihmer Z. Measurement of platelet monoamine oxidase activity in healthy human volunteers. Acta Physiol Hung 1986; 68 (1):19-24.

36. Baron M, Levitt M, Perlman R. Human platelet monoamine oxidase and the menstrual cycle. Psychiatry Res 1980; $3: 323-7$.

37. Holzbauer M, Youdim MBH. The oestrous cycle and monoamine oxidase activity. Br J Pharmacol 1973; 48 (4):600-8.

Received July 1, 1996/January 20, 1997

Corresponding author: Dr. Gülinnaz Alper, Ege Universitesi Tıp Fakültesi, Biyokimya Anabilim Dalı, 35100 Bornova İzmir, Turkey 